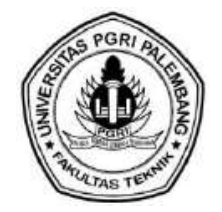

\title{
ANALISIS PENAMBAHAN LIMBAH BAKARAN ABU AMPAS TEBU SEBAGAI FILLER CAMPURAN ASPAL AC WC
}

\author{
Agus Setiobudi $^{1^{*}}$, Amiwarti $^{2}$, Doni Tamara ${ }^{3}$ \\ ${ }^{123}$ Program Studi Teknik Sipil Fakultas Teknik Universitas PGRI Palembang \\ *Corresponding Author, Email : setiobudi808@gmail.com
}

\begin{abstract}
ABSTRAK
Penelitian ini bertujuan untuk mengetahui campuran aspal AC WC pada nilai-nilai karakteristik propertis Marshall Test. Penelitian ini merupakan metode kuantitatif dengan data diambil di laboratorium AMP PT. Hka Aspal Beton UP Palembang. Hasil penelitian dengan penambahan abu ampas tebu dengan variasi $1 \%$, $2 \%$ dan $3 \%$ dengan hasil yang mendekati spesifikasi di variasi 1\%, dimana hasil pengujiannya yaitu Nilai Stabilitas Marshall sebesar 1169,0 kg. Nilai Vim sebesar 4,54\%. Nilai VMA (Void In Marshall Anggregat) sebesar 16,92\%. Nilai VFB (Void Filled Bitumen) sebesar 73,14\%. Nilai flow (kelelahan) sebesar 3,70 mm. dan Nilai Marshall Quotient sebesar 324,69 kg/mm. Dari hasil pengujian yang dilakukan dengan penambahan filler abu ampas tebu sebesar 1\%, 2\% dan 3\% tersebut menghasilkan aspal AC WC yang belum sesuai spesifikasi Umum 2010 Revisi 3 Dinas PU Bina Marga
\end{abstract}

Kata Kunci : Filler, Bakaran Ampas Tebu, AC WC, Marshall Test

\section{PENDAHULUAN}

Perencanaan geometrik jalan merupakan suatu perencanaan rute dari suatu ruas jalan secara lengkap, menyangkut beberapa komponen jalan yang dirancang berdasarkan kelengkapan data yang didapat dari suatu hasil survey/lapangan, kemudian dianalisisberdasarkan acuan perencanaan yang berlaku. Acuan perencanaan yang di maksud adalah sesuai dengan standar perencanaan geometrikyang dianut di Indonesia.

Tanah asli dialam jarang sekali dalam kondisi mampu dalam mendukung beban berulang lalu lintas kendaraan tanpa mengalami deformasi yang besar. Karena itu dibutuhkan suatu struktur yang dapat melindungi tanah dari beban roda kendaraan. Struktur ini disebut perkerasan. Perkerasan berfungsi untuk melindungi tanah dasar dan lapisan-lapisan pembentuk perkerasan supaya tidak mengalami tegangan dan rengangan yang berlebih oleh akibat beban lalu lintas. Perkerasan merupakan struktur yang diletakan pada tanah dasar, yang memisahkan antara beban kendaraan dengan tanah dasar yang berada dibawahnya. Perkerasan akan mempunyai kinerja yang lebih baik, bila perencanaan dilakukan dengan baik dan seluruh komponen-komponen utama dalam sistem perkerasan berfungsi baik. campuran berasapal untuk perkerasan lentur di rancang menggunakan Marshall konvensional. Untuk kondisi lalu lintas berat perencanaan Marshall menerapkan pemadatan benda uji 2 x 75 tumbukan dengan batas rongga campuran antara 3 dan 5. Hasil pengujian pengendalian mutu menunjukan bahwa kesesuaian parameter kontrol dilapangan seringkali tidak terpenuhi untuk mencapai persyaratan dalam spesifikasi sehingga kinerja perkerasan jalan tidak tercapai. Keterbatasan metode Marshall Test adalah ketergantungannya terhadap kepadatan setelah dilalui kendaraan untuk mencapai rongga udara yang disyaratkan. 


\section{TINJAUAN PUSTAKA}

Perkerasan jalan adalah bagian dari jalur lalu lintas yang bila kita perhatikan secara struktural pada penampang melintang jalan, merupakan penampang struktur dalam kedudukan yang paling sentran dalam dan .merupakan urat nadi dari suatu kontruksi jalan. Perkerasan dalam kondisi baik maka arus lalu lintas akan berjalan dengan baik dengan lancar, demikian sebaliknya kalau perkerasan jalan rusak, lalu lintas akan sangat terganggu.

Apapun perkerasan jenis lalu lintas, dia harus dapat memfasilitasi sejumlah pergerakan lalu lintas, apakah berupa jasa angkutan manusia, atau jasa angkutan barang berupa seluruh komonitas yang diijinkan untuk berlalu lalang disitu. Dengan beragam jenis kendaraan dengan angkutan barangnya, akan memberi variasi beban ringan sampai sedang. (Saodang, 2005:1).

Menurut Suprapto (dalam Iqbal, Amiwarti \& Setiobudi, 2020), tanah saja biasanya tidak cukup kuat dan tahan, tanpa adanya defomasi yang berarti, terhadap beban roda berulang. Untuk itu perlu lapis tambahan yang terletak antara tanah dan roda atau lapis paling atas dari bahan jalan. Lapis tambahan ini dapat dibuat dari bahan khusus yang terpilih (yang lebih baik), yang selanjutnya disebut lapis keras / perkerasan / pavement.

\section{Lapisan Perkerasan Jalan}

Menurut (Suprapto 2004) pada mulanya kontruksi perkerasan di kelompokan menjadi perkerasan lentur (flexible) dan perkerasan kaku (rigid).

\section{Perkerasan Lentur (flexible pavament).}

Bahan kontruksi perkerasan lentur menggunakan bahan bahan ikat (aspal, tanah liat) dan batu, perkerasaan ini umunya terdiri dari 3 lapisan atau lebih yaitu: lapisan permukaan, lapisan pondasi bawah, dan yang terletak di atas tanah.

\section{Lapisan Perkerasan Kaku}

Perkerasan kaku umumnya terdiri dari atas dua lapis yaitu lapisan dan lapisan pondasi. Lapisan pondasi atas dan lapisan pondasi bawah memberikan sumbangan yang bersar terhadap daya dukung perkerasan terutama didapat dari plat beton. Hal tersebut disebabkan oleh sifat beton yang cukup kaku sehingga dapat menyebarkan beban pada bidang yang luas dan menghasilkan tegangan yang rendah pada lapisan-lapisan dibawahnya.

\section{Material perkerasan Jalan}

Menurut Gunadarma (ISBN: 979-8382-1:87-93), pemilihan material harus didasarkan pada beberapa pertimbangan, seperti persyaratan struktur perkerasan ekonomis, keawetan, kemudahan dikerjakan dan pengalaman setempat. Material untuk perkerasan kaku meliputi material granuler atau agregat yang umumnya mengandung 90-95\% agregat berdasarkan persen berat atau 70-75\% Volume.

Material untuk perkerasan jalan meliputi batu pecah, batu belah dan batu kali. Bahan pengikat yang di pakai yaitu aspal, semen dan tanah liat 


\section{Mineral filler}

Menurut Saodang (2005:157), mineral filler adalah agregat halus yang lolos saringan no.200, berupa abu (dust). Abu kapur atau abu semen diyakini dapat memperbaiki antara aspal dan agregat. Untuk persyaratan mineral filler dapat dilihat pada tabel berikut :

Tabel 1. Persyaratan Mineral filler

\begin{tabular}{|l|c|c|}
\hline \multirow{3}{*}{ SIFAT UMUM } & Kadar air & Max 1\% \\
\cline { 2 - 3 } & Gumpalan partikel & Tidak ada \\
\cline { 2 - 3 } & Bukaan saringan $(\mathrm{mm})$ & \% Lolos saringan \\
\hline \multirow{3}{*}{ GRADASI } & 0,6 & 100 \\
& 0,15 & $90-100$ \\
& 0,074 & $70-100$ \\
\hline
\end{tabular}

\section{METODE PENELITIAN}

Metode kuantitatif dinamakan metode tradisional karena metode ini cukup lama digunakan sehingga sudah mentradisi sebagai metode untuk penelitian. Metode ini disebut sebagai metode positivistik karena berlandaskan pada filsafat positivisme. Metode ini sebagai metode ilmiah karena telah memenuhi kaidah-kaidah ilmiah yaitu konkrit empirisobjektif terukur rasional dan sistematis. Metode ini disebut metode kuantitatif karena data penelitian berupa angka-angka dan analisis menggunakan statistik. Metode penelitian kuantitatif dapat di artikan sebagai metode penelitian yang di gunakan untuk meneliti pada populasi atau sampel tertentu, pengumpulan data menggunakan instrument penelitian, analisis data bersifat kuantitatif/statistik, dengan tujuan untuk menguji hipotesis yang teleh ditetapkan. Metode penelitian ini lebih suka menggunakan teknik analisis mendalam (indepth analysis), yaitu mengkaji masalah secara kasus perkasus karena sifat suatu masalah satu akan berbeda dengan sifat dari masalah lainnya.

Penelitian ini dilakukan di laboratorium AMP PT. Hka Aspal Beton UP (Unit Produksi) Palembang, dimana jenis penelitian ini adalah penelitian eksperimen di laboratorium berupa pengujian aspal dengan bahan bakaran ampas tebu.

\section{Teknik Pengumpulan Data}

Adapun metode penelitian yang digunakan penulis adalah sebagai berikut :

1. Pengumpulan data sekunder dilakukan dengan cara mencari data dan mencari bahan dari jurnal atau buku yang berkaitan dengan pemanfaatan limbah kertas. Kemudian browsing internet sebagai masukan-masukan guna menyelesaikan laporan ini.

2. Pengumpulan data primer, dengan cara melakukan observasi dan penelitian secara langsung di laboratorium guna mendapatkan data-data yang diperlukan secara lengkap. Pada penelitian ini sampel dibuat sebanyak 6 benda uji dengan menggunakan variasi campuran $0 \%, 1 \%, 2 \%$ dan 3\%. Masing-masing variasi campuran dibuat 2 sampel dengan total sampel 8 buah.

Pelaksanaan penelitian dilakukan di laboratorium AMP PT. Hka Aspal Beton UP (Unit Produksi) Palembang yang beralamat di jalan Mayjen Yusuf Singedekane Musi 2 Palembang. 


\section{Peralatan Penelitian}

Semua peralatan yang dibutuhkan untuk penelitian ini tersedia di laboratorium, dan peralatan yang digunakan adalah saringan/ayakan saringan digunakan untuk campuran

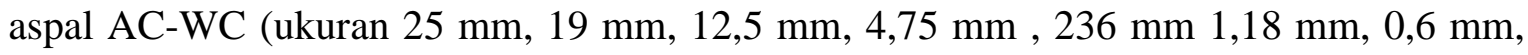
0,3 $\mathrm{mm}, 0,15 \mathrm{~mm}, 0,075 \mathrm{~mm}$ dan pan), timbangan kapasitas $20 \mathrm{~kg}$ (ketelitian 1 gram untuk agregat kasar), timbangan digital kapasitas $2 \mathrm{~kg}$ (ketelitian 2 gram untuk agregat halus dan filler), gelas ukur, tabung silinder, kertas hisap (karton), batang penumbuk berdiameter $16 \mathrm{~mm}$ panjang $610 \mathrm{~mm}$, mistar, cetakan benda uji (mold), talam atau pan, oven, piknometer, mesin uji Marshall, mesin uji Los Angeles, satu set alat dongkrak, ember, kuas, palu karet, jangka sorong, thermometer, kompor, bak perendam, kuali, Marshall Test

\section{Bahan Penelitian}

Bahan-bahan yang digunakan dalam penelitian ini meliputi material penyusun untuk komposisi campuran aspal AC WC yang ditambahkan bakaran abu ampas tebu sebagai filler bahan tambahannya, dimana:

1. Agregat kasar (split) agregat kasar yang digunakan pada penelitian ini yaitu agregat alami yang dipecahkan dengan ukuran $1 / 2$ dan $1 / 1$ dimana material berasal dari Bojonegara Serang Banten.

2. Agregat halus agregat yang digunakan pada penelitian ini berupa abu bata yang berasal dari Bojonegara Serang Banten.

3. Filler penelitian ini berupa bakaran abu ampas tebu untuk campuran aspal yang berasal dari limbah ampas tebu.

4. Aspal curah (bitumen) yang digunakan adalah aspal penetrasi $60 / 70$ yang berada di laboratorium AMP PT. Hka Aspal Beton UP (Unit Produksi) Palembang. Dalam hal ini aspal curah yang dipakai adalah merk shell 60/70 dari Singapura.

\section{HASIL DAN PEMBAHASAN}

Hasil penelitian sebelumnya (Iqbal, Amiwarti, \& Setiobudi, 2020) campuran AC WC normal untuk menentukan kadar aspal optimum (KAO) dengan pengujian propertis Marshall Test yang hasilnya bisa dilihat di tabel sebagai berikut:

Tabel 2. Hasil Marshall Tes AC WC Normal Untuk KAO

\begin{tabular}{|l|l|l|l|r|r|r|r|r|}
\hline \multirow{2}{*}{ No } & AC WC & \multirow{2}{*}{ Satuan } & \multirow{2}{*}{ Spesifikasi } & \multicolumn{6}{|c|}{ Kadar Aspal \% } \\
\cline { 5 - 9 } & Normal & & & 5,0 & 5.5 & 5,7 & \multicolumn{1}{l|}{6,0} & \multicolumn{1}{c|}{6,5} \\
\hline 1 & Density & gr/cm & - & 2,274 & 2,276 & 2,246 & 2,284 & 2,288 \\
\hline 2 & VMA & $\%$ & Min 15 & 14,94 & 15,33 & 16,92 & 15,48 & 15,78 \\
\hline 3 & VFB & $\%$ & Min 65 & 63,54 & 69,29 & 73,14 & 74,60 & 80,35 \\
\hline 4 & VIM & $\%$ & $3,0-5,0$ & 5,45 & 4,71 & 4,54 & 3,93 & 3,10 \\
\hline 5 & Stability & $\mathrm{kg}$ & Min 1200 & 1144,1 & 1267,0 & 1169,0 & 1181,9 & 1097,3 \\
\hline 6 & Flow & $\mathrm{mm}$ & $2,0-4,0$ & 3,35 & 3,45 & 3,70 & 3,60 & 3,85 \\
\hline 7 & MQ & $\mathrm{kg} / \mathrm{cm}$ & Min 250 & 341,6 & 367,5 & 324,69 & 328,3 & 282,5 \\
\hline
\end{tabular}

Sumber: Hasil Penelitian di laboratorium AMP PT. Hka Aspal Beton UP (Unit Produksi) Palembang 
Berdasarkan tabel diatas, maka hasil pengujian campuran aspal AC WC normal dalam penentuan kadar aspal normal (KAO) di dapatkan bahwa pencampuran aspal yang sesuai speksifikasi dengan kadar aspal 5,7\% dimana propertis pengujian Marshall Test sebagai berikut :

a. Nilai Density di dapat sebesar 2,246 gr/cc.

b. Nilai VMA(void in Marshall Anggregat) sebesar 16,92\%.

c. Nilai VFB (Void Filled Bitumen) sebesar 73,14\%.

d. Nilai VIM (Void in Mix) sebesar 4,54\%.

e. Nilai stabilitas marshall sebesar $1169,0 \mathrm{~kg}$.

f. Nilai flow (kelelahan) sebesar 3,70 mm.

g. Nilai Marshall Quotient sebesar $324,69 \mathrm{~kg} / \mathrm{mm}$.

Tabel 3. Perbandingan Nilai-Nilai Marshal test Campuran Aspal AC WC Normal dan Variasi Penambahan Filler Ampas Tebu Secara Keseluruhan

\begin{tabular}{|c|c|c|c|c|c|c|}
\hline $\begin{array}{c}\text { Kadar } \\
\text { filler }\end{array}$ & $\begin{array}{c}\text { Stabilitas } \\
(\mathbf{K g})\end{array}$ & VIM & VMA & VFB & Flow & $\begin{array}{c}\text { MQ } \\
(\mathbf{k g} / \mathbf{m m})\end{array}$ \\
\hline $0 \%$ & 1196,0 & 4,54 & 16,92 & 73,14 & 3,70 & 324,69 \\
\hline $1 \%$ & 1202,4 & 6,24 & 20,14 & 59,46 & 4,65 & 236,96 \\
\hline $2 \%$ & 1244,0 & 8,57 & 20,41 & 58,06 & 5,05 & 227,09 \\
\hline $3 \%$ & 852,8 & 16,71 & 27,51 & 39,37 & 5,5 & 165,26 \\
\hline Spek & Min 1200 & $\mathbf{3 , 0 - 5 , 0}$ & Min 15 & Min 65 & $\mathbf{2 , 0 - 4 , 0}$ & Min 250 \\
\hline
\end{tabular}

Berdasarkan tabel penelitian di atas dapat disimpulkan bahwa pengaruh kuat tekan Marshall Test dengan menggunakan filler ampas tebu sebagai campuran aspal AC WC dengan variasi penambahan filler 1\%, $2 \%$ dan 3\% mengalami kenaikan dan penurunan terhadap pengujian Marshall Test, dimana hasilnya pengujian masih sebagian besar belum masuk ke dalam spesifikasi Umum 2010 Revisi 3-Dinas PU Bina Marga, filler 1\%, $2 \%$ dan 3\% hampir semuanya tidak sesuai spesifikasi yang di tentukan tetapi ada variasi yang mendekati spesifikasi, yaitu variasi campuran $1 \%$

\section{KESIMPULAN}

Pengaruh kuat tekan Marshall Test dengan menggunakan ampas tebu sebagai filler pada campuran aspal AC WC dari hasil penelitian dapat di simpulkan secara keseluruhan bahwa pengaruh kuat tekan Marshall Test dengan menggunakan ampas tebu sebagai campuran aspal AC WC dengan variasi penambahan filler 1\%, 2\% dan 3\% semuanya tidak masuk spesifikasi Umum 2010 Revisi 3 Dinas PU Bina Marga namun ada satu variasi yang lebih mendekati spesifikasi yaitu variasi campuran $1 \%$

\section{DAFTAR PUSTAKA}

Hardiyatmo, Hary C. (2007). Perancangan Perkerasan Jalan dan Penyelidikan Tanah. Gajah Mada University Press. 
Iqbal, M., Amiwarti, A., \& Setiobudi, A. (2020). Analisis Penambahan Limbah Las Karbit Sebagai Filler Campuran Aspal AC WC. Jurnal Deformasi, 5(1), 43-47

ISBN 979-8382-47-1. Rekayasa Jalan Raya, Guna Darma.

Pedoman. (2010). Spesifikasi Umum Marga (Revisi 3), Devisi 6 PerkerasanAspal

Saodang, MSCE. IR.(2005). Kontruksi Jalan Raya. Bandung, Nova.

Suprapto. (2004). Bahan dan Struktur Jalan Raya, Biro Penerbit KMTS FT UGM Yogyakarta.

Wingnall, Artgur. Kendrick, Piter S. Acil, Roy. Capson, Malcolm. (2003). Proyek Jalan, Edisi Keempat Penerbit Erlangga Jakarta.

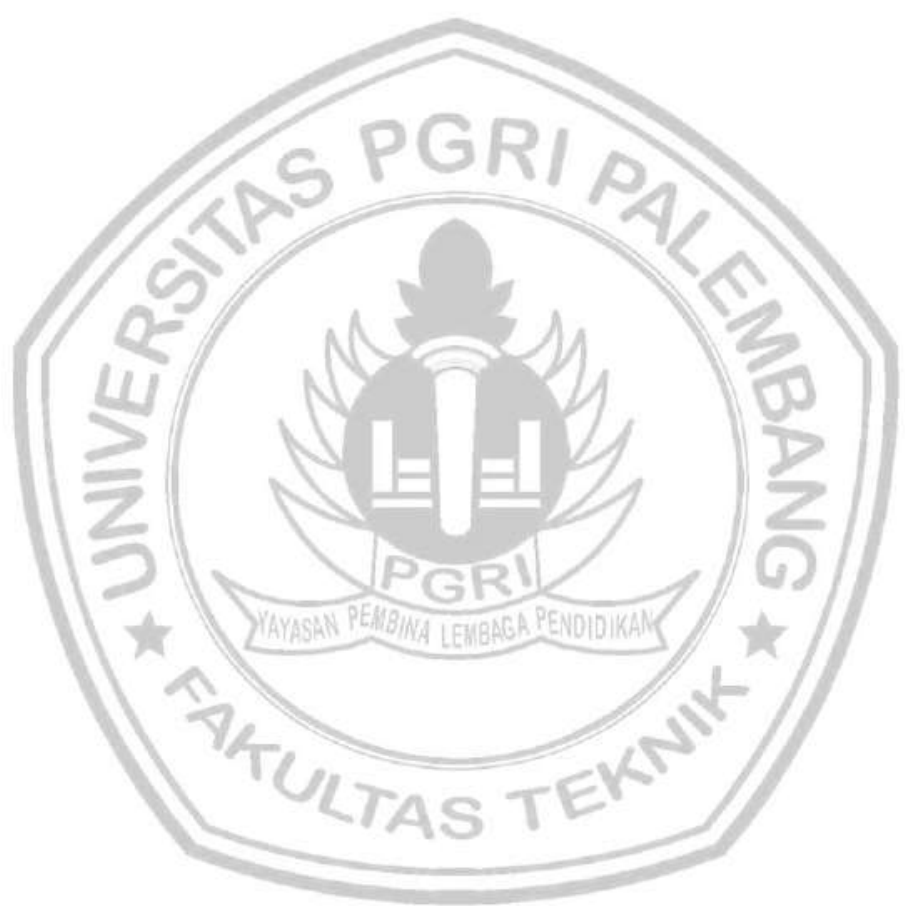

